\title{
IR23
}

\section{D- Static Modeling for Carbonate Mushrif Formation in Buzurgan Field}

\section{W. K. Hamdan* (Ministry of Oil) \& S. N. AL-Jawad (Ministry of Oil)}

\section{SUMMARY}

The aim of this study is to build a Model for carbonate Mishrif Formation in Buzurgan Field. The Mishrif formation is considered to be an overall progradational marine shelf sequence; rudist shells occupied different locations on the Mishrif carbonate platform.

The Mishrif Formation in Buzurgan field can be divided into four reservoirs oil-bearing zones (MB11, MB21, MC1, MC2) depending on petrophysical properties that have been interpreted from log and core data. The MB11 unit ranges in thickness (20-48m.) and it is an upper most oil-bearing unit which has good porosity. The MB21 has the maximum thickness of $(77-88 \mathrm{~m})$ and it is characterized by higher porosity. The MC1 unit is much smaller in thickness ranging from (17-30m) and it has good porosity. The MC2 unit, it is the lower most oil-bearing unit which has good porosity.

The grain-supported of microfacies and then high reservoir properties are placed and increasing at the crests of two domes and to the south-west of Buzurgan field, while the mud-supported microfacies increasing at the north-east of the Buzurgan field. That mean the Mishrif reservoir units are governed by the stratigraphic - structural traps.

A basic 3D structural geological model of an area of $219 \mathrm{~km} 2$ (225000 3D cells) was calculated using pre-existing well data .The 3D static geological model ( structures, facies, and petrophysics models ) has been built for Mishrif formation in the Buzurgan field using Petrel software. Structural contour maps have been constructed for MB11, MB21, MC1 and MC2. These structural contour maps show that the Buzurgan structure is composed of two domes of 29x6 and 9x5 km, running along a NW-SE direction. MA is divided into 2 layers; MB11 unit has been divided into 4 layers, while MB21 unit has been divided into 6 layers due to the heterogeneity in the facies, $\mathrm{MC} 1$ unit has been divided into 4 layers and the MC2 unit has been divided into 3 layers. 